\title{
THE BUSINESS SCHOOL IN THE ANTHROPOCENE: PARASITE LOGIC AND PATAPHYSICAL REASONING FOR A WORKING EARTH
}

Gasparin, Marta * a; Brown, Steven ${ }^{\mathrm{b}}$; Green, Williamª, Hugill, Andrew ${ }^{\mathrm{a}}$, Lilley, Simon ${ }^{\mathrm{a}}$, Quinn, Martin ${ }^{\mathrm{a}}$, Schinckus, Christophe ${ }^{\mathrm{c}}$, Williams, Mark ${ }^{\mathrm{a}}$, Zalasiewicz, Jan ${ }^{\mathrm{a}}$

*corresponding author $\underline{\operatorname{mg} 352 @ \text { leicester.ac.uk }}$

A = University of Leicester, $B=$ Nottingham Trent University, $C=$ Taylors University

Acknowledgment:

This article emerged from the inaugural annual workshop of the Anthropocene Research Group in 2019- a joint initiative between the Schools of Geology and Business at the University of Leicester supported by Leicester Institute of Advance Studies (LIAS) and the School of Business. Discussing the management learning and education with colleagues from natural science and computer science allowed to initiate an interdisciplinary discussion. We would like to thank the reviewers for their time and efforts. Their critical and insightful contributions really supported the development of this article. We also thank the special issue guest editors, Robin Holt, Morten Sørensen Thaning, Mike Zunde, Boston Russ Vince and Bill Foster, who provided guidance and thought-provoking suggestions in the special issue workshop in Copenhagen. Finally, we would like to thank TEMA Institute at Linköping University for the lively debate on an earlier version of the paper.

This paper has been supported by the ESRC grant number ES/S006060/1 
Authors Bio:

Dr Marta Gasparin is Associate Professor in Innovation and Design Management at the University of Leicester. She is undertaking an ESRC New Investigator research project on slow design-driven innovation to develop slow business models, and to theorise how design practices can reduce the exploitation of natural and human resources, whilst increasing product lifespans and driving innovation based on quality, local traditions and sustainable values.

Steven Brown is Professor of Social and Organizational Psychology at Nottingham Trent University. His research interests are around social remembering amongst 'vulnerable' groups and service user experiences of secure mental health care. He is author of Vital Memory and Affect (with Paula Reavey, Routledge, 2015), Psychology without Foundations (with Paul Stenner, Sage, 2009) and The Social Psychology of Experience (with David Middleton, Sage, 2005).

Dr William Green is the Deputy Dean of Research for the College of Social Sciences, Arts and Humanities. He researches the role of new technology on the interface between people, technology and their environment. This research has led to recent studies of innovation and emerging technology in the healthcare and consumer research sectors, investigating the impact of emerging technology on practice in the health sector.

Prof Andrew Hugill is Founding Professor of Creative Computing at the University of Leicester. He is a composer and musicologist, computer scientist and pataphysician. Hugill's research publications include the books The Digital Musician (Routledge, 2016); 'Pataphysics: A Useless Guide (MIT Press, 2012); and The Orchestra: A User's 
Manual (2004). His musical compositions include: Catalogue de grenouilles (1987), Island Symphony (1995) and Thirty Minutes for Diplacusis Piano (2019).

Prof Simon Lilley is Professor of Information and Organisation at the University of Leicester School of Business where he was also Dean of School between 2010 - 2015. Simon's academic background is in psychology, information management and technology in organisations. He has worked on several funded projects, most recently for Innovate UK and the ERDF Knowledge Transfer scheme and is widely published in academic journals and books.

Dr Martin Quinn is Associate Professor in Regional Development and Public Policy. He has worked on more than twenty funded projects investigating public policy, economic development, place leadership and identity, and the use of culture and heritage as a driver of development. He has worked with a range of public sector organisations including carrying out research for Government as well as private sector businesses.

Prof Mark Williams is Professor in Paleobiology, with a wide research background that includes oceanography, evolution and biogeography, biostratigraphy, forensic and environmental investigations, stable isotope geochemistry, climate proxies and the application and ground-truthing of numerical climate models. He has been a leading member of the international Anthropocene Working Group since its founding.

Prof Christophe Schinckus is professor of finance and Head of the School of Finance and Economics at Taylor's University in Malaysia. He published more than 100 papers in peerreviewed journals. Christophe has just published a book on Econophysics (Oxford University 
Press) while doing a second $\mathrm{PhD}$ at the University of Cambridge, UK. He is currently involved in his third $\mathrm{PhD}$ in Physics applied to Finance.

Prof Jan Zalasiewicz's research has been built around the evolution of the Earth System in its physical, chemical and biological aspects, with strong focus on the geological effects of human impact. Key themes include: Science and significance of the Anthropocene concept, palaeoenvironments, palaeontology and palaeoclimate of the Early Palaeozic era, environmental change of the Pleistocene and Holocene epochs, practical and philosophical underpinnings of the Geological Time Scale, history and development of the Earth sciences 


\title{
THE BUSINESS SCHOOL IN THE ANTHROPOCENE: PARASITE LOGIC AND PATAPHYSICAL REASONING FOR A WORKING EARTH
}

\begin{abstract}
We have entered the Anthropocene: a new geological epoch in which human activities, led by business interests, have inexorably compromised the Earth System. The current failure to provide a comprehensive and systematic response to this transition does not result from a lack of reason but is instead the manifestation of a generalized crisis in communication. Drawing from the work of Serres, we analyze how the roots of this crisis lie with the "parasite logic', which has prevented reasoned responses to the Anthropocene. To work through this crisis, it is necessary to adopt different forms of reasoning and imagination to reshape the rational basis of management education. We propose to do it through pataphysics, a science subjecting dominant modes of rationality to a divergent thinking of the absurd and proposing playful forms of reasoning. Pataphysics provides a mechanism for developing 'imaginary solutions' to the current situation, that can disrupt anthropocentric forms of reason and reasoning, and further serve to slow down the endless cycles of inclusion and exclusion that arise from parasite logic. Finally, we propose slow design as an example of an 'imaginary solution' that comes from this process of conceptual and practical deacceleration.
\end{abstract}

Keywords: Change and innovation, Decision making, Ethical issues, Leadership education, Learning under conditions of rapid environmental change, Management development, Management education, Philosophy 


\section{INTRODUCTION}

The Anthropocene is defined by a new and dangerous climate state brought about through the dominance of a single species (Homo sapiens) breaking through the photosynthetic energy barrier, the human-directed evolution of other species and the increasing interaction of the biosphere with technology (e.g. Zalasiewicz et al., 2014; Williams et al., 2015; Waters et al, 2016; Steffen et al., 2018; Zalasiewicz et al, 2018). The irreversible material consequences of the transition to a new geological reality have been clearly outlined (see Zalasiewicz et al., 2019). It is unquestionably the case that "mankind has become a global geological force in its own right" (Steffen et al., 2011a: 843). However, despite the starkness of the evidence, there is, to date, no comprehensive global holistic response that might help identify the precise level of environmental danger and provide strategies to mitigate its impacts. It has been argued that this inertia arises because the Anthropocene represents such a dramatic change in human history that it is 'unthinkable' (Ghosh, 2016), that it defeats the rational capacity of organizations and institutions to categorize and accommodate the threats which it poses (Campbell, McHugh \& Ennis, 2019), and that it leads to the collapse of the vision of collective human future (Latour 2017, 2018). But the focus is on the difficulty of 'thinking' the Anthropocene can overlook the ways in which the effects of climate change are already a brutal reality in many geographical regions (Yusoff, 2018), where they have intensified a plethora of local strategies for collaborative survival (Tsing, 2015; Povinelli, 2016). We argue that the problem is best described as a generalized crisis of communication between different forms of knowledge and practice, across distinct publics and interest groups, and, more profoundly, between humans and the Earth System itself.

The Earth System comprises the biosphere (all living organisms and their interactions with rock, soil, air and water), hydrosphere (all the waters on the Earth), atmosphere (set of 
gases surrounding the Earth) and lithosphere (the rocky outer part of the Earth) (Zalasiewicz et al., 2019). Its individual components are intimately interconnected and co-evolve, so that a change in the utilization of materials from the land will have concomitant effects on all other components of the system, as with the burning of fossil fuels - stored within the lithosphere which when liberated changed the atmosphere, hydrosphere and biosphere (Choquet, 2019). The resources of the different components of the Earth System are all finite, so that overutilization of its component parts also has a concomitant effect on other components, for example the use of nitrogen fertilizers (Edwards, 2017), which impact strongly and negatively on aquatic ecosystems into which they drain. To provide lasting, mutualistic and sustainable solutions to the Earth's environmental problems requires an understanding of this Earth System complexity, and it needs human systems to evolve to allow non-human actors to be active subjects of the conversation. This clearly requires substantive interdisciplinary work (Görg et al., 2019) accompanied by a wholesale rethinking of current forms of social and economic organizing (Wright et al., 2018). It is no longer possible to conceive of doing 'business as usual' in even the immediate future (Mitchell, Lemon \& Lambrechts, 2020), although this is not challenged in management research (Nyberg \& Wright, 2020). The coronavirus pandemic is an example of how the Earth System shows that there are multiple intersecting forms of value creation of human and non-human actors. Business as usual concept needs to be challenged, and the relation between different organisms taken into account- as the ongoing spread of the current mutation of the coronavirus has demonstrated in relation to rapidly emerging transformations in social, economic and political relations.

Developing the required kind of communication between Business Schools and Earth System Scientists presents considerable challenges (Mychajliw, Kemp \& Hadly, 2015). Business and management education continues to teach and promote human-centered economic models that are profoundly insensitive to the complex interdependencies between 
human action and the irreversible environmental changes that constitute the currently, and rapidly, unfolding climate reality (Brueckner, Spencer \& Paull, 2018; Nyberg, Spicer \& Wright, 2013). But a potentially more far-reaching issue is with the ways in which communication is conceptualized in relation to interdisciplinarity and more broadly. As Michel Serres has observed, there is a persistent tendency to see communication as a matter of control and exchange for instrumental purposes:

Have you noticed the popularity among scientists of the word interface -which supposes that the junction between two sciences or two concepts is perfectly under control? On the contrary, I believe that these spaces between are more complicated than one thinks. This is why I have compared them to the Northwest Passage ... with shores, islands, and fractal ice floes. Between the hard sciences and the so-called human sciences the passage resembles a jagged shore, sprinkled with ice, and variable ... It's more fractal than simple. Less a juncture under control than an adventure to be had. (Serres \& Latour, 1995: 70)

The approach to interdisciplinarity posits a neutral relationship between two bodies of knowledge between which information is exchanged, where the clarity with which the messages are sent from one to the other are received is central. But Serres points to the lack of concern for what happens to messages in the communicative space between sender and receiver, where information may be distorted, deferred, transformed, translated or simply lost. When communication is treated as an entirely rational process of information exchange in a controlled medium, the critical role of the middle space is ignored (Serres, 1982a, 1982b). This claim can be extended to the broader webs of communication around the Anthropocene, where it is assumed that bringing stakeholders into a reasoned conversation around climate change will produce desired outcomes, if the evidence can be clearly transmitted and received without distortion. Even communication with non-human actors 
within the Earth System can be treated in the same way, under the rubric of 'listening to nature' (Latour, 2004). These are all instances of an anthropocentric model of communication fashioned on classical notions of unmediated dialogue between speakers and listeners who exercise mastery over the communicative space.

What we are calling a 'generalized crisis of communication' arises from the failure of the anthropocentric model to describe the complex middle space in which a whole host of other parties and actors enter into and shape any given communicative act. In the same way that any interdisciplinary exchange necessarily includes a range of concepts, instruments, institutional structures and funding regimes, efforts to 'dialogue' with the Earth System pass by way of innumerable biospheric, atmospheric, technological and multi-species actors. It is not a question of simply 'including' these 'missing masses' (see Latour, 1992), since human communication around the Anthropocene already depends upon their presence. There is no rational speech situation outside of the atmospheric conditions which makes it possible. Nor is it a matter of just 'hearing the voices' of the absent elements of the Earth System, because this would involve subordinating the middle space to existing forms of human-defined reason (Dalby, 2015). What is instead required is a non-anthropocentric approach to communication which is able to show how the middle or third space is both critical to and also disruptive of our efforts to engage with climate change.

In this paper we outline how the late French philosopher Michel Serres's concept of parasitism provides just such an approach. Serres (1982a) conceives all forms of communication through a triadic structure where the signal that passes from sender to receiver encounters disruptive forces or 'noise'. This results in a dynamic shifting of positions as the intervening forces - which Serres personalizes as 'the parasite' - struggle with the communicative pair to intercept and redirect the signal. Since a signal is fundamentally defined in relation to noise, the parasite can be seen as the very conditions of 
communication, and that which perpetually threatens its existence. Whilst Serres treats parasitism as a process at work within all organic life, humans are increasingly a special case. Recent human history has been defined by global technological developments (what Peter Haff (2014) calls the 'technosphere') that have resulted in hominids departing from the evolutionary rhythms of other species - a process Serres $(2018,2019)$ terms 'hominescence'. The unconstrained expansion of the technosphere renders humans as literally the biggest parasites on the planet, and, figuratively, through the globalization of communication circuits, as the most parasitized of all species. The 'great acceleration' of population, industrialization and globalization that started in the mid-20th century (Steffen, Crutzen \& McNeill, 2007) was the pathway to the current generalized crisis of communication.

Describing the middle space may help to better diagnose the problems we face in developing reasoned responses to the Anthropocene, but it does not necessarily point out the means to do so. Serres (1995a, 2018) argues that we cannot reverse the 'great acceleration' to do so is no longer within human power - but we can act to slow it down or to turn it back in itself by engaging with the planetary interdependencies through which it was constituted (for example, the relationship of mutual dependency between the current state of lithosphere and the extractive aspects of the technosphere). This engagement cannot be conducted through the application of established modes of instrumental reason, which impose humanderived categories, but must seek emergent, speculative forms of reasoning. We propose that a range of strategies be adopted which enable the suspension or productive disruption of rationality in order to create the space for relationally derived reasoning.

Classically, it is the role of 'metaphysics' to provide the tools for reorganizing our contemplation and reasoning around observable empirical phenomena (i.e. 'physics'). However, the challenge of generating non-anthropocentric reasoning from within existing rationalities requires a 'pataphysical' intervention. Pataphysics, is the "science of imaginary 
solutions, which symbolically attributes the properties of objects, described by their virtuality, to their lineaments" (Jarry, 1965a: 145). Derived in part from the work of Alfred Jarry, pataphysics maintains a similar relationship to metaphysics as the latter has to physics. For example, in Jarry's novel Exploits and Opinions of Dr Faustroll, pataphysician, the titular character is introduced in the following way:

Doctor Faustroll was sixty-three years old when he was born in Circassia in 1898 (the 20th century was [-2] years old). At this age, which he retained all his life, Doctor Faustroll was a man of medium height, or, to be absolutely accurate, of ( $8 \mathrm{x}$ $1010+4 \times 108+5 \times 106)$ atomic diameters; with a golden-yellow skin, his face clean-shaven, apart from a few sea-green mustachios, as worn by king Saleh; the hairs of his head alternately platinum blonde and jet black, an auburn ambiguity changing according to the sun's position; his eyes, two capsules of ordinary writing-ink flecked with golden spermatozoa like Danzig schnapps. (Jarry, 1965a) At the physical level, this introduction provides a range of empirical details that appear to be derived from very different perspectives and concerns (i.e. history, atomic measurement, barbering and drink connoisseurship). At a metaphysical level, the concern is with which of these descriptions can be said to co-exist in the same world, and those which must necessarily be excluded (e.g. was Dr Faustroll actually sixty-three in 1898 or at some other point). But at a pataphysical level, we must treat all statements as equally valid since pataphysics is the science of the particular which deems every possible description to be an exception and therefore subject to equivalence (Hugill, 2012). We are then invited to speculatively imagine the shape of a universe supplementary to this one - or 'imaginary solution' - in which this is possible. Pataphysical solutions may appear to be absurd but they are not irrational, being instead the outcome of immense precision in description - note the atomic calculation of Dr Faustroll's height and the minute specification of the drink which 
his eyes resemble. Pataphysics simultaneously admits the convergent thinking of rationalism and the divergent thinking of the apparently impossible in order to go beyond the limits of anthropocentric reason. As Ruy Launoir observes:

We represent the real according to our usage of it or according to our very anthropomorphic perceptions of it. The lineaments could therefore be either the outline of these practices, or, which amounts to the same thing in the end, a sort of elementary structure - we know not what - of what is made manifest. All our ideation bears its mark, and no doubt always in exactly the same way, even though circumstances and indeed individuals vary. We cannot suppress these lineaments $[\ldots]$ but we can at least divert our habits and free up thinking. We must, by considering the possible ways in which we can imaginatively extend all the aspects of an object, be able to combine them in order to obtain a new representation of a linear 'something'; pataphysical freedom will be attained at the moment when we can think of objects at once as ordinary and in many other ways, being conscious only of the differences in ingenuity between these representations. This does not exclude other interpretations: one could say, more simply, that the pataphysician proposes to decorate with new solutions our representations of poverty-stricken, linear, 'world.' (Launoir, 2005: 22-23)

Pataphysics is at times humorous and can appear playful but is utterly serious in its practice of imagining worlds that suspend the limits of established rationalities and forms of reasoning through a process of disruption and slowing down. As we will go on to describe, pataphysical strategies have resulted in transformative practices and inventions based on laws governing contradictions and exceptions, including non-anthropocentric reasoning.

Whilst not directly informed by pataphysics (except insofar as everything is pataphysical), slow design is a strong example of an emerging mutualistic business model 
that attempts to push beyond anthropocentric forms of organizing. It is a fully realized 'imaginary solution' to the contradictions of maintaining a stake in global capitalism alongside investing in local political ecology. Slow design also provides a practical illustration of what a slowing down of relations to elements of the Earth System might resemble. It furthermore serves as an object lesson in the kinds of non-anthropocentric practices and forms of reasoning which might inform business and management education.

This paper then asks: how can we comprehend and begin to address the communication crisis which has prevented reasoned responses to the Anthropocene? In addressing this, we ask what forms of reasoning might assist in envisaging complex symbiotic and mutualistic relationships as constituent parts of business and management and how they may be cultivated both within the Business School and more broadly.

Our argument will be organized through an initial discussion of Michel Serres's (1982a) concept of parasitism and parasite logic which will act as the means to outline the shape of the problem constituted by the communication crisis. We will then proceed to describe how strategies derived from pataphysics can disrupt anthropocentric forms of reason and modes of reasoning and further serve to slow down the endless cycles of inclusion and exclusion that arise from parasite logic. Slow design will then be discussed as an example of an 'imaginary solution' that comes from this process of conceptual and practical deacceleration. We conclude with some reflections on how the challenge of the Anthropocene may be taken forward in business and management education. The contribution made by this paper is fourfold. Firstly, we make an informed intervention in debates around the Anthropocene in Business Schools that cuts between the hitherto polarized poles of minor adjustments to business practice and a complete rejection of existing models of management (what Dalby (2016) calls the 'good and the bad') and provides a practical basis for beginning to 'think' this intractable object. Secondly, we provide a clear 
introduction to a range of thinkers and concepts which exemplify non-anthropocentric reasoning. Thirdly, we show how the application of parasite logic and pataphysical techniques can generate forms of reasoning that slow down rational action and point towards a mutualistic relationship with the excluded third space. Finally, the paper serves as an example of a novel and unexpected interdisciplinary collaboration which may prove instructive (in one way or another) to readers seeking to develop such partnerships.

\section{BUSINESS AS USUAL: THE INEVITABILITY OF PARASITE LOGIC}

Michel Serres's work, which extends to over 45 books published in his lifetime, covers an enormous range of topics and themes, and has been enormously influential across a range of disciplines, not least through the way his thinking inspired the development of ActorNetwork Theory (see Callon, 1980, 1998; Latour, 1987, 1994). One way to summarize his work (see Brown, 2002, 2005) is that it is principally concerned with how humans may think and live when they have radically transformed their relationship with both the Earth System and the very nature of human life itself, a critical juncture he refers to as 'hominescence' (Serres, 2019). Key to understanding his approach is a unique form of reasoning that concerns the paradoxical nature of the communication known as 'parasite logic' (Serres, 1982a).

The origins of classical reason lie in the logical principle of the excluded middle. It is necessarily the case that a given proposition is either true, or its negation is true. It cannot be the case that both are true. This creates two distinct logical positions by removing the possibility of a middle or shared ground. From this principle, the modern notions of identity, difference, subject and object which constitute the grammar of rational action are derived, including digital technology, which relies on Boolean logic (a lot of time and energy is being spent 'disambiguating' for the benefit of computers, when ambiguity is the condition of 
nature). Serres (1982b) argues that the structure of communication demonstrates a paradox in the principle. For two subjects to communicate they require a third element, the medium, through which to transmit a signal. However, as we have previously described, this immediately introduces noise, a third partner, which is simultaneously the condition of possibility of the communicative relation and that which acts to perpetually disrupt and destabilize it. Noise oscillates between inclusion and exclusion.

In naming the middle or third position as 'parasite', Serres (1982a) alludes to three homologous operations of 'taking without giving'. In French, le parasite can refer to the uninvited guest who ingratiates themselves into a household, the biological organism which feeds upon another with no reciprocity and the static which interrupts a signal. For Serres, the parasite is the fundamental element of any relation, of any form of organizing, because order establishes itself out of and through a broader 'noisy' environment against which it is then defined. Organizing anticipates parasitism, it tries to draw a boundary or set up a barrier to keep the parasites out. But that order which is constituted is effectively 'borrowed' or 'stolen' from the world upon which it ultimately depends. Behind every anticipated parasitic act is a prior parasitism - "the parasite parasites the parasites" (Serres, 1982b: 55). Life itself is parasitic:

Life works; life is work, energy, power, information. It is impossible to translate this description into an ethical discourse. It is thus, it must be thus; I really don't know. The work of life is labour and order but does not occur without borrowing from elsewhere. It makes order here but undoes order there. And it reinforces disorder and noise ... One parasite chases out the other, as one disorder chases out the other. (Serres 1982b: 88)

The idea that the constitution of organizational or system boundaries involves a complex and indeterminate interplay between order and disorder has been fruitfully 
developed within organization studies (e.g. in Robert Cooper's 1986, 1991 work $^{1}$ ). Serres (1982a) pushes further in insisting that the emergence of one form of order always comes at the cost of either disrupting an existing set of relations, or of preventing the emergence of an alternative form of order. Violence and appropriation are then intrinsic to the very nature of organization itself (Serres, 2011). The recent literature on the 'dark side of organizations' (Linstead, Maréchal \& Griffin, 2014), which treats violence as an obscure or hidden part of organizing, profoundly underestimates the extent to which all organizing follows the logic of the parasite (Brown \& Reavey, 2017). However, parasitism is not just 'taking without giving', it also forges novel kinds of order within and between existing relations. The parasite invents or catalyzes a mode of communication that did not previously exist. The uninvited guest who joins a dinner table, for example, 'pays' for the food he/she eats by telling outrageous stories, whilst at the same time catalyzing solidarity amongst the diners who must now band together to expel the unwanted visitor (Serres, 1982a). The 'noise' introduced by a parasite may impel a system to transform itself to either incorporate or (temporarily) eradicate the intrusion.

Treating organizations as parasites perhaps surprisingly opens up a new way for Business and Management Schools to engage with the Anthropocene. If rational action is in fact underpinned by parasite logic in the way that Serres proposes, then the pressing social and economic problems in which the business and management education can be seen as complicit are not entirely human inventions. Rather they are the enactment at the hominid level of a parasitic operation which is fundamental to life itself (Serres, 2012). However, our failure to recognize and analyze the actual parasitic basis of modern economies has led us to ignore the complex interdependencies within the Earth System on which parasitism is based.

\footnotetext{
${ }^{1}$ The then out-of-print copy of Serres's The Parasite first read by one of the authors was borrowed from Bob Cooper's bookshelf.
} 
Organisms do not act as parasites on all occasions, which would clearly be unsustainable in terms of the conservation of energy, but instead cycle through a variety of mutualistic relations. One of those relations is that of serving as host or carer, such as with parent-child relationships, a relation that is equally fundamental to life (see Serres, 2015). The parasite may parasitize other parasites, but it must equally accept the position of being parasitized. If we cannot willingly and graciously allow our economic models to be opened up as hosts to other parasites, then they will remain entirely unsustainable. It is this basic principle derived from parasite logic that is absent from business and management education.

Parasite logic provides a way to understand how the Anthropocene itself emerged. Serres (2019) points to two crucial periods on human history. The first is the transition from the late Palaeolithic into the Mesolithic and Neolithic around 4,000 years ago. During this period animal husbandry and settled agriculture were first adopted, along with viniculture. Serres (1989) refers to these practices as 'soft technologies' defined by their relational character. The appropriation of animals or yeasts and bacteria is parasitic in nature, but it also involves humans and other species living together in close proximity. These early communities were appropriated through violence and exclusion, as a way of marking out human property, in a manner derived from the marking of animal territories with urine and scents (Serres, 2011). However, as a consequence of this being-together, humans developed close communicative bonds with those that they parasitized, resulting in an 'acculturation' or 'reciprocal domestication' of species to one another. Human learned how to live together with domesticated animals, and vice versa, resulting in an oscillation of positions between host and parasite - 'in order to prepare this common site it is enough for the parasite to become host and hosts parasites, reciprocal domestication becoming then another name for symbiosis' (Serres, 2019: 87). 
The second period is the industrial revolution and the development of combustion and mechanized tools that Serres (1995b) groups together as 'hard technologies' (Dalby 2018 similarly refers to 'firepower'). These technologies enabled human parasitism to operate at a truly global scale. The violence and appropriation that was hitherto contained by soft technologies became exponentially expanded, ultimately leading towards the 'Great Acceleration' of the mid-20th century and the irreversible changes in planetary conditions marked by the 'golden spike' (Zalasiewicz et al., 2015). Serres (2011) argues that the pollution and environmental damage which began in this period was not an accidental byproduct of industry, but rather another means of hominid territorial marking on a global scale. But crucially, this 'mastery' over nature demonstrated through territorial appropriation resulted in a distancing of humans from other species. We no longer dwell amongst the species and resources that we parasitize (Serres, 2019), and have consequently lost the prior reciprocal communicative bonds. The 'golden spike' also marks the emergence of the current communication crisis.

Becoming the biggest parasite of all on the planet has come at a terrible cost. As Serres notes:

We are now, admittedly, the masters of the Earth and of the world, but our very mastery seems to escape our mastery. We have all things in hand, but we do not control our actions. Everything happens as though our powers escaped our powers. (Serres \& Latour, 1995: 171)

As parasites, humans both master the Earth System and depend upon it for continued resources to exploit. But following the logic that the parasites parasitize the parasites, it is entirely predictable that more nimbler parasites - such as coronaviruses - may exploit that supposed mastery (Serres, 2012). At the same time, the Earth System depends upon us, in the sense that the fate of entire swathes of the biosphere and the atmosphere rests on humans 
seizing control of their own actions. The project for future business and management education can then be simply stated: how do we gain mastery over our own mastery?

What needs to be accomplished, Serres (2011) argues, is a turning of that mastery back on itself, in order to slow the pace of the violence and damage caused by our own parasitism, which simultaneously maintains the forward advance of our knowledge and technologies. It is a not a question of turning back to clock to some idealized former period of agrarian human history, but rather of de-escalating parasitic violence and shifting towards a renewed mutualism or 'reciprocal living together'. Serres (2019) uses the example of the eradication of bacteria and viruses. Our impulse is to protect our own health through their entire eradication. This not only increases the chance of their reappearance in a mutated, resistant form, but also raises the question of by what right we deny existence to another organic life. Moreover, the current coronavirus pandemic shows that there are multiple intersecting forms of value creation where differing human and non-human actors are positioned as either parasites or hosts depending upon how one wishes to map the overall ecology. Finding a way in which we might mutualistically co-exist, rather than intensifying the cycles of parasitism and exclusion is the more creative, ethical, and ultimately sustainable path.

Heikkurinen et al. (2019) argue that recognizing symbiotic relations between humans and other species will mean developing a 'multidimensional understanding of agency' in order to recognize the blurring of boundaries between actors. But from Serres's perspective, this is akin to shutting the stable door after the horse has bolted. Non-humans have always exercised agency - albeit not of the self-contained, intentionality-driven kind fetishized in the western philosophical tradition - and our own sense of agency has been constituted through parasitizing theirs (from viniculture and sericulture all the way through to contemporary immunology). What is instead urgently need is a way of formalizing our symbiotic relations through according mutualist species their due status as legal subjects. Serres (1995a) terms 
this a 'natural contract' that is to be established with 'Biogea' (i.e. the Earth System) and its inhabitants. The purpose of this contract is to formally enshrine the existing bonds of dependency between species to force humans towards a default position of symbiosis, where human planetary actions are a matter for collective, multi-species negotiation - "we should no longer be the masters and possessors of nature. The new contract becomes a rental agreement" (Serres, 2011: 72).

The success of the natural contract will be determined by the extent to which communicative relations can be re-established between humans and the various species and components of the Earth System. Overcoming the communication crisis is the means by which to address the ecological crisis, by way of formalized symbiosis. If we are able to once again communicate across varied species and more widely, then it is possible to conceive of a 'thinking with' rather than 'against' the Earth System, and on this basis to find more creative ways to 'pay' for the order and value that we humans borrow. Brown describes the implications for business and management education in following way:

Thinking like Biogea means understanding strategy from the perspective of a tree, marketing from the belly of the snake, finance amidst the excess of frogspawn, innovation amongst coral. Management education needs to be 'de-hominized' if we are to understand how we can live with rather than against Biogea. (Brown, 2016: 157)

If we cannot imagine for ourselves how to redesign economic and social systems for symbiosis, then using the bonds of mutual dependency to learn from other species becomes crucial. Trees, for example, appropriate territories and enter into conflicts with one another (Wohlleben, 2017), as well as participating in dense microbial 'social networks' that link one another - the 'wood-wide web' (Helgason et al., 1998). However, their relative lifespan and modes of acting can render their strategies invisible to humans. Taking the time to live with 
plant life may prove instructive in developing non-anthropocentric mutualistic forms of social and economic organizing (see Kohn, 2013).

In summary, Serres's work clarifies the nature of the generalized communication crisis around the Anthropocene. Rational action creates a paradox through its exclusion of the third space that is the conditions of possibility of communication. Parasite logic, on the contrary, enables the play of inclusion and exclusion to be made visible and enables an account of how humans have accelerated and exponentially expanded the parasitism inherent in life to a global scale. Crucially, it also forces us to understand that inclusion alone is not sufficient, we must find a way to mutualistically co-exist within the third space. Slowing down parasitism and forcing hominids back towards mutualistic positions enables a 'facing up' to the challenges of the Anthropocene, but would crucially require re-opening communicative relations with multi-species actors and broader aspect of the Earth System. However, whilst Serres clearly outlines what the goals would be for non-anthropocentric business and management education, his work has rather less to say about how this could be done and the strategies which might be deployed to force thinking outside of existing parasitic relations. For this, we will need to turn in a pataphysical direction.

\section{BEYOND PARASITISM: PATAPHYSICS}

Pataphysics $^{2}$ is a term first used in the early 1880s by a group of French schoolboys in Rennes as a way of mocking their physics teacher. One of their number, the anarchic poet, writer and painter Alfred Jarry (1873-1907) developed the 'science' of pataphysics, firstly in the play Ubu Roi (Jarry, 1965b), which caused a massive scandal at its première in 1896, and subsequently in a series of surrealistic novels and other writings. Jarry declared that the

\footnotetext{
${ }^{2}$ Readers familiar with 'pataphysics will observe that we have not used the apostrophe before the word throughout this article. Alfred Jarry himself only ever used the apostrophe on one occasion. We have decided to omit it from the main text in the interests of editorial consistency, apart from a brief explanation of its 'correct' usage, and its usage in titles and quotations.
} 
“actual orthography (should be) 'pataphysics, preceded by an apostrophe so as to avoid a simple pun" (Jarry 1965b: 192), a spelling which wrong foots the reader and has the effect of trying to exclude the word from the dictionary. Jarry's works, in particular $U b u$, were very influential in the development of certain art movements in the 20th century, such as Dadaism, Futurism and Surrealism. The idea of pataphysics, however, has outlived all these historical “-isms" and has penetrated into areas far beyond the arts. Its influence may be detected today as a kind of subversive presence in almost all fields of human activity, from the natural sciences to the social sciences, from technology to the humanities (Hugill, 2012).

Our argument has been for the need to shift from anthropocentric rationalities through a slowing down and disruption of parasitic relations in order to reopen communication with the excluded third space. Pataphysics provide a means to do this through subjecting dominant modes of rationality to a divergent thinking of the absurd and proposing playful forms of reasoning.

This contrast with the approach to modern business, which is mostly driven by convergent thinking. Divergent thinking is typically dismissed as irrelevant, counterproductive or "foolish" (Izak, 2015). Divergent thinking comprises multiple spontaneous, non-linear and free-flowing outcomes from an initial stimulus, adding up to a healthy diversity in reasoning, and a healthy neurodiversity. There is a group whose contributions in this area can be guaranteed. Autistic and other neurodivergent people are hard-wired to think divergently, and their contributions to business in areas such as the digital technology sector are well documented, but they remain under-employed in the wider economy (Griffiths et al., 2016). Divergent thinking belies the extent to which, as a mode of thought, it depends upon the rigorous application of structure and procedures, often derived from formal mathematics. In this sense, pataphysics does not correspond to the kind of illogical thinking that Vince (2019) describes as arising from "the structuring and unsettling 
effects of unconscious dynamics" (Vince, 2019: 954), as it is logical in its approach. This is particularly apparent in the work of Georges Perec (1969), whose novel La Disparition is written entirely without the letter 'e'. This meticulous application of an arbitrary writing constraint forces the production of an entirely innovative text where there can be no easy recourse to existing idioms.

At one level pataphysics can be understood as being akin to an injunction to continuously 'think outside the box'. Pataphysical logic often follows a three-step process, modelled on Jarry's physics $\rightarrow$ metaphysics $\rightarrow$ pataphysics sequence. A typical example from Perec runs as follows:

If physics proposes: "you have a brother and he likes cheese", then metaphysics replies: "If you have a brother, he likes cheese". But 'Pataphysics says: "You don’t have a brother and he likes cheese." (Perec, 1968: 52)

Perec's example plays with syllogistic form to offer three linked propositions. Our understanding of the form leads us to expect that the final concluding proposition will provide a logical thread by making use of the excluded middle - an either/or specification of the relationship between the two parts of the of the major and minor propositions 'brother' and 'cheese'. But the conclusion takes the form both/and which affirms all possible states of the prior relationship. The coexistence of opposites, along with the equivalence of all judgements, is a core aspect of pataphysics. Pataphysics insists that we imagine the world where this is possible.

Pataphysics anticipated Whitehead's (1920/2004) critique of the 'bifurcation of nature' through its deliberate according of agency to non-human entities. Jarry lived with a pair of owls and a chameleon, and his posthumously published Faustroll novel includes the central character of a dog-faced baboon "Bosse-de-nage", who provides comments, ripostes, critiques, and reactions to narrative events through a repeated disyllable: "ha ha". The 
venerable Collège de 'Pataphysique, which began in Paris immediately after World War II, included among its founders a matamata turtle. Another early member was Lutembi, a crocodile living in Lake Victoria, who dispensed justice by devouring the guilty or sparing the innocent. Lutembi became the fourth Vice-Curator of the Collège, the highest-ranking living creature after the fictional Curator, Dr Faustroll (Foulc, 2007). The President of the Netherlands Academy of 'Pataphysics (NAP) - whose members have made significant contributions to environmental actions - is 'Woudagemaal', the largest steam pumping engine in the world. This machine was elected President because "the Netherlands is a super prosthesis, a hydraulic system of ditches, locks, dikes and dams, a gigantic imaginary solution" (NAP, 1972). In formally electing animals or machines to such roles, pataphysics enacts precisely the legal according of the status of speaking subject to non-humans that Serres calls for with the natural contract. This deliberately challenges modern notions of the autonomy and superiority of humans in their efforts to master and geo-engineer the natural world.

There are pataphysical organizations in most countries in the world today. Some of them consist of a single individual (sometimes with multiple identities) and others have hundreds of members, both human and non-human. Their organograms invariably reflect the exceptional and contradictory nature of pataphysics itself. The Collège de 'Pataphysique, which has very many adherents worldwide, is structured ironically like a cross between a university and the Catholic Church (Jarry's twin targets were science and religion). Most pataphysical organizations use the pataphysical calendar, which starts from the birth of Jarry and has thirteen equal months, each consisting of 29 days. One of these is an imaginary day that can be inserted at will.

Pataphysics makes use of a set of conceptual-practical operators including: plus-minus (the simultaneous co-existence of mutually exclusive opposites); clinamen (a small swerve or 
deviation within a predictable field); syzygy (the surprising encounter of apparently unrelated entities); and anomaly (the exception or contradiction, the thing that does not fit). Whilst pataphysics in itself is not designed to be useful, it does promote a different way of thinking that subverts more familiar and rational processes with real-world applications, proposing playful forms of reasoning. Jarry makes this point about a watch:

Why should anyone claim that the shape of a watch is round - a manifestly false proposition - since it appears in profile as a narrow rectangular construction, elliptic on three sides; and why the devil should one only have noticed its shape at the moment of looking at the time? (Jarry, 1965b)

If an object is divorced from its supposed function, one can notice other things about it. The pataphysical plus-minus (or as Hugill (2012) refers to it antinomy) identifies apparently contradictory states of affairs or situations and forces them to co-exist. It reverses the logic of the excluded middles to that of inclusion, liberating energies and possibilities from objects described.

The poet and scientist Christian Bök describes the pataphysical clinamen (after Epicurus) as "the smallest possible aberration that can make the greatest possible difference" (Bök, 2002: 45). For example, in 1914 the pataphysician Marcel Duchamp began creating "readymades" which involved making slight alterations to ordinary manufactured objects. These led directly to the formation of a completely new art market, and had a massive influence on marketing, advertising and even manufacturing. The key point here is that global changes can be initiated by ramifying and articulating small unpredictable events that arise locally (De Duve, 1987), creating not only new relationships among things, but also proposing a new form of respect for things in themselves. Duchamp created the readymades, common objects elevated to the status of art by the artist (De Duve, 2005). Duchamp's approach to aesthetic is relational: the readymade is a kind of rendezvous (De Duve, 1989, 
1997), during which the concept of a priori object is manifesting in front the artist, it shows itself, and in this process it declares itself as art (De Duve, 1989). The artist recognizes it, accepts it, and he inscribes the date, hour, minute, and the title of the readymade as information, declaring "this is art". In this perspective, objects and authors are nothing but the conditions of their encounter. The artist, by not providing a fine art commodity but a mundane object, turns out to be a manufacturer. Scandalously, Duchamp's once utilitarian object proves capable of going further and become art.

Syzygy is an astronomical term that refers to the alignment of three or more bodies. In pataphysics this metaphorically gives rise to the 'aha!' (or 'ha ha') moment at which a connection between apparently unrelated things is recognized. This demonstrates the sense of 'deeply serious' nature of the playfulness crucial to pataphysics. Whilst the selection of objects to compare can appear random or downright bizarre (e.g. picked from a box at home or a random backpack), it is only through allowing the creative freedom to invent new and unexpected forms of relations that it becomes possible for conceptually or geographically remote objects to be linked together. In physics, constellations provide one example of such linkage and quantum entanglement another.

Finally, pataphysics proposes a reversal in the way that normativity and exceptionalism is considered. For pataphysicians, every phenomenon (including the laws of nature themselves) is an anomaly. There is no general state from which they depart - things are characterized by the way they do not fit rather than by their common features. Here, the limits to human ingenuity and failure reveal the anomalous nature of things. Humans regard the misguided and the failed as unwelcome in a business system that is geared towards 'success'. However, success can retrospectively appear as in fact a gigantic failure. Pataphysics reflects on failures and produces creative solutions (Gasparin, Green, and Schinckus, 2019). From a pataphysical perspective, failure is intrinsically as interesting as 
success. In 2017, the artist Isabelle Desjeux installed a pataphysical lab at the ArtScience Museum in Singapore. Visitors were provided with a Lego building station, a photography station and a bean-counting station, and advised that they were going to fail. The failed attempts were exhibited, but not before important discussions were had about the prospect of failure. Desjeux has elaborated this kind of thinking into a scientific study of 'failomics' (Desjeux, 2010).

It is crucial to recognize that for Jarry (1965a), pataphysics is $a$ science; indeed, as he puts it in Faustroll, it is the science (see Hugill, 2012). The rigorously imaginary approach of pataphysics has shown itself to have relevance for science and technological development. For example, pataphysical techniques may be seen at work at a number of pivotal events in the history of science. Since 1952, The American Miscellaneous Society (AMSOC) has presented an annual award of a stuffed albatross for pataphysical feats such as: 'finding a way to observe the ocean without going to sea' (to Paul Scully-Power in 1987 - a trained oceanographer who flew on the sixth flight of the space shuttle Challenger); or 'for unique and non-conventional ideas concerning the oceans' (to the oceanographer John Isaacs in 1980 - which included ideas that 'ranged from extracting energy from ocean salinity gradients to providing Los Angeles with fresh water from icebergs towed up the Pacific from Antarctica' - Knauss, Lill \& Maxwell, 1998: 35). One real-world outcome of this nonsense was the science fictionish idea to drill through the ocean floor into the Earth's mantle, which actually took place in 1961. Although this was technically a failure (they got nowhere close to the mantle) - it showed that deep-ocean drilling was possible, and out of that emerged the Deep Sea Drilling Project (later the Ocean Drilling Program), arguably the most important, expensively funded and revolutionary Earth Sciences program of the second half of the 20th century. 
The early pioneers of the personal computer were strongly influenced by the radical ideas conveyed to them through the celebrated Issue 13 of the Evergreen Review entitled “What is 'pataphysics?", published in 1960. Ted Nelson, the visionary who coined words such as "virtuality" and whose Project Xanadu anticipated hypertext and the World Wide Web by decades; and Howard Rheingold, whose work in the 1980s with virtual communities such as The WELL and the Whole Earth Catalog prefigured the rise of social media, have openly acknowledged the influence of pataphysics. Apple's celebrated exhortation to "think different" in the 1990s seems also to have emerged from this influence. The Pataphysical Studios in San Francisco remains influential in the "maker culture" of technology-based DIY, and have run education workshops based on their Pataphysical Slot Machine.

The techniques which pataphysics offers upend the classical reasoning of the excluded middle in a way to similar to parasite logic. They slow down rational action by forcing it to confront impossible situations, where the excluded middle space is now an integral part of the relations between subjects and objects. It also forces a suspension of the limits of the thinkable. If all possible states of matter in a specific set of relations are equally affirmed, and all equally anomalous, then judgment becomes paralyzed, suspended and decelerated.

However it would be a mistake to reduce pataphysics to a mere set of techniques. Indeed, the Collège de 'Pataphysique tried for many years to have itself officially declared a Public Inutility - the quality of having no practical use. The espoused 'uselessness' of pataphysics again serves to disarm the instrumentality of reasoning, forcing us to stay with the imaginary solution and puzzle upon its both/and structure.

We have here presented an actually existing science and practice which has developed a broad range of techniques to implement the kind of inclusive both/and reasoning found within parasite logic. Pataphysics illustrates what happens when communication is treated not as the instantaneous passage of messages across a controlled medium, but rather as a 
perpetually extended 'adventure' where the affirmation of all possible states results in the creation of imaginary solutions to apparently impossible propositions and circumstances. It is exactly this kind of rigorous, precise and 'seriously playful' practice which is required to shift towards non-anthropocentric thinking with business and management schools. As we have shown, there are existing examples of scientific and innovative practices that have explicitly taken forward pataphysical ideas. In the following section we describe an example of a business model which draws parasite logic and pataphysics together.

\section{SLOW-DESIGN: A MODEL FOR MUTUALISTIC ORGANIZATIONS}

Parasitic logic and pataphysical reasoning can be brought together to explore new modes of organizing in the Anthropocene. There are numerous examples which might be used, including permaculture initiatives (Roux-Rosier, Azambuja \& Islam, 2018) and alternative food networks (Beacham, 2018). These all share a commitment to 'slowing down' parasitic relations in order to focus on communication with non-human actors within the excluded third space through imaginative solutions. These practices may be tiny clinamen or 'swerves' within the global economy, but they are potentially deviations with significant consequences. Slow design-driven innovation is a key example here because it is explicit in its aim of encouraging humans to acknowledge and confront their dependency on the Earth System, and vice versa. Strauss and Fuad-Luke (2008: 1) depict slow design as: "an approach predicated on slowing the metabolism of people, resources and flows, [which] could provide a design paradigm that would engender positive behavioural change".

Slow design first evolved in Italy as an approach to making high value goods that produce sustainable livelihoods (Manzini, 2014). Key to this was fostering the use of renewable - and where possible - local sources of energy and material and designing products that could be returned to nature at the end of their functional life. Slow design- 
driven innovation is an emerging movement in fashion and design that recognizes the importance of taking the time to produce. This does not necessarily refer to the actual production process itself, which can be variable, but rather in the configuration of natural resources that are used (Strauss \& Fuad-Luke, 2008). Through this approach, slow designers embrace the idea of increasing rather than decreasing their dependence on the natural resources they engage with, slowing down the design processes to continuous reflect upon the character of this dependency, and thinking about the multiple effects they have on the evolving Anthropocene context. This can be described as the building in of environmental resilience within an economic model, to borrow a term from biodiversity literature $(\mathrm{Li}$, Crépin \& Folke, 2018).

Slow design-driven innovation does not observe the usual timings of markets and their rapid cycles of parasitic activity. Instead, production times are tied to the natural cycles of the raw materials, respecting their own timings, rather than seeking to accelerate them through artificial measures. Slow designers work closely with local craft-makers to mobilize creativity and design processes which reflect upon local identity, understand what constitutes local heritage, and envisage how these could be embedded in the shape of contemporarylooking products using traditional technology (Gasparin, Green \& Schinckus, forthcoming). This typically involves recourse to longstanding 'soft technologies' of communal artisanal production in close proximity with resources rather than 'hard technologies' (or 'firepower') of industrial scale production. This focus on soft technologies gives slow design-drive innovation a different relationship to the past and the future of Anthropocenic human history. As Serres puts it:

What is left that's lasting? Yes, the soft. Water lasts longer than earth, air longer than water ... signs longer than fire. Here is my theorem in full: the hard does not last, only the soft lasts. (Serres, 2012: 192) 
A slow design approach involves thinking about the after-life of the product: the energy is not only sourced locally, but it is also given back to the environment. This works toward 'imaginary solutions' framed in terms of the wider growth of the biosphere. For example, some designers have created garments that can be buried in the garden once a customer wishes to dispose of them, to make compost for plants. This is a pleasing syzygy - a buried garment rotting into compost - that gives rise to an 'aha!' moment of accomplishing smallscale sustainability. This is in contrast to approaches that operate with a mindset oriented towards design for globalized fashion markets, where there may be a concern with using initially recycled materials, but the methods of disposing of the garment are not are not factored in. A slow design approach also includes a reduction in air and shipping travel, which reduces the environmental impact of global commerce.

The accepted wisdom in innovation processes is that new products are either 'incremental' or 'radical' and deliver either gradual improvements to existing benefits and behaviours or bring about significant changes (Frattini, Dell'Era \& Rangone, 2013: 177). In both instances there is a failure to engage with the Earth System as a crucial actor, from both a specifically Anthropocene context of accelerating global change and in a more general geological perspective of long-term cycling of matter and energy. Haff $(2014,2019)$ uses the term 'technosphere' to refer to all existing technological objects and products, from computers and the internet, to tower blocks and motorways, river dams and farm irrigation systems, along with all the human systems in which they are bound up, including schools and universities, local councils and national governments, company boards and trade unions. Since the 'Great Acceleration' (Steffen, Crutzen \& McNeill, 2007), the technosphere has become a major planetary presence, joining the lithosphere, atmosphere, hydrosphere and biosphere. The technosphere has developed an essentially parasitic relationship towards the biosphere, appropriating and redirecting an ever-greater proportion of its mass and energy 
flows, and poisoning it through burgeoning and unrecycled waste products. Seen from this perspective, the technosphere appears to have developed its own dynamics and 'needs' which are different from those of the myriad human decisions and actions that are currently driving it, in the same way as the large-scale dynamics of the biosphere are different from the individual actions and needs of cats, mice and daisies. Humans do not, at this point, exercise 'mastery' over the technosphere but are rather captured or 'mastered' within it, being forced to maintain it (for without the food energy and shelter it gives us, most humans would soon die). Compared with the biosphere, which has had billions of years of evolution and trial-anderror to mutualistically adapt to the other 'spheres' of the Earth as a long-lived, resilient system the technosphere is very new, and is now evolving and growing explosively, in effect "rac(ing) ahead like a forest fire without much concern for its own longevity" (Haff, 2019). Whilst traditionally design has dealt with unconsciously shaping and growing the technosphere through focusing on $\mathrm{R} \& \mathrm{D}$ improvements and technological innovations to increase competitiveness, slow designers realize that design impacts the biosphere, causing a dangerous disequilibrium in terms of climate and living organisms.

The technosphere is the major accomplishment of "hominescence" (Serres, 2019) - the moment when human evolution breaks apart from other processes within the Earth System to pursue unconstrained entirely parasitic pathway, with irreversible consequences. As Serres ironically observes, this means that the fate of the entire planet comes to rest with humans and at precisely the moment when control over the process is ceded (to the technosphere) 'everything depends upon us. And through new and unexpected loops, we ourselves end up globally depending on the things that depend globally on us' (2019: 10). This double movement requires urgent analysis within finance, business and commerce in order to grasp the constraints on, and degrees of freedom of, human actions that might be aimed at steering it or modifying the hominescent movement of the technosphere. We may come to see 
'innovation', for instance, as something which is not to be pursued unthinkingly as an end in itself, but as a process with a spectrum of forms and consequences to choose between. Within this, slow design-driven organizations have shifted towards being aspiring mutualistic entities, through seeking different modes of relations and looking for solution to achieve a slower rate of change and damage towards the biodiversity of the planet. We see in this an 'imaginative solution' to the problem posed by Serres's idea of the 'natural contract'. Traditionally industrial scale innovation has, in practice, reduced access to local resources by locals, endangered local species, and placed stress on the environment with the use of pesticides for increasing productivity (Debs, 2013). This result is environmental and cultural fragmentation (Cutcher, 2014). Slow design innovation, by contrast, acts to slowing down and strengthening the dependency between organizations and the natural resources and local craft communities they work with. This is a 're-acculturation' process that restores communicative bonds between human communities and the Earth System and opens the way for novel and unexpected form of learning.

Slow design engages with both humans and non-humans, and mobilizes different actors, competences and skills to work towards a biodiverse ecosystem marked by coherent and slow growth (Gasparin, Green \& Schinckus, forthcoming). Slow designers are working closely with natural scientists in order to integrate a range of previously excluded third parties into their business models, including local plants, insects, and animals. Slow innovation is something of a 'plus-minus' or 'antinomy' in that brings the parasitism of the market together with the mutualism of biodiversity (see Klein, 2015). Rather than being fast and competitive, innovation becomes slow and 'geocentric'. The call to slow down and to imagine forms of organizing with rather than against insects or plants may sound as absurd as Jarry's Faustroll, or Serres's notion of a 'natural contract', but such ideas reflect the manner in which life has flourished on Earth for over three billion years, and may work towards the 
long-term survival of humans and a functional biosphere. Opening organizations up to this geocentric time beyond the instrumental or clock-time may prove vital to their survival (Holt \& Johnsen, 2019).

\section{DISCUSSION \& CONCLUSION: MANAGEMENT AND LEARNING FOR A WORKING EARTH}

The Anthropocene is the object of our paper because it is increasingly the object to which all business and management practices will have to refer to in some way. Within a comparatively minute slice of geological time - equivalent so far to just one human lifetime there has been irreversible modification of planetary conditions, including increasing levels of climate change and biodiversity loss (Steffen et al., 2011b; Zalasiewicz et al., 2015). The 'Great Acceleration' that began in the mid-20th century (Zalasiewicz et al., 2015) has resulted in a doubling of the Earth's surface phosphorus and reactive nitrogen levels, a onethird increase in atmospheric carbon dioxide (reaching levels not seen on Earth since three million years ago), an order-of-magnitude increase in erosion and sedimentation driven by landscape reshaping ('terraforming'), the proliferation and global dispersal of novel Earth materials such as concrete, plastics, aluminium and artificial radionuclides, and persistent organic pollutants (Zalasiewicz et al., 2019), along with unprecedented changes to animal and plant communities (Williams et al., 2019). To paraphrase Michel Serres, it is no longer up to us to decide whether or not we want to do business as usual.

So how does business and management education respond to this potentially overwhelming challenge, and how can management learning change? At the heart of the matter is changing the way we think about the rationalities and modes of reasoning which dominate the ways problems are framed and social and economic models of organizing are conceived. This means to go beyond transforming business schools in adopting ethics and 
sustainability (Akrivou \& Bradbury-Huang, 2015). It means changing the modes of reasoning. As we have argued, we cannot even begin to do this until we have first confronted the generalized communication crisis which has been brought about by the paradoxes inherent in the traditions of reasoning we have inherited. Current management modes of reasoning implies that inputs, outputs and processes can be arranged, measured, planned, verified and reviewed, looking at the past, analyzing the present and imaging the (short-term) future (Holt, 2018), in an array of inclusion and exclusion. Mitchell, Lemon \& Lambrecht (2020) indicate that one of the problems of management learning education is its inwards focus, without a strategy that runs counter to the resilient system characteristics, nor, as we argue, mutualistic.

As Serres (1982a; 1982b) shows, the law of the excluded middle in the form of either/or propositions leads to the expulsion of a third space that has its conditions of possibility. The clarion call to communicate better, faster, wider and with ever more stakeholders actually accelerates this process of exclusion. The more that we try to push out noise, clarify the signal and build a fence around the bountiful gardens of business and management education to keep out the parasite, the more it/they return in a viral fashion. Cooper's $(1986,1991)$ work presciently predicted that a lack of concern for what happens at the boundaries of organizing would mask symbolic and actual violence. In a similar fashion it is not enough to say that we must work on inclusivity if what that means is that those who are excluded are welcomed back as guests entirely on our terms. Noise, the parasite, the excluded middle space, are all what makes any form of organizing possible. In Anthropocenic terms, human forms of organizing are constructed from and against the myriad elements which constitute the Earth System in a way that is itself parasitic. If we do not allow ourselves to be parasitized in turn, if we cannot 'pay back' the cost of human parasitism by taking on the 
place of the host, or better yet, by developing mutualistic relationships, then we will maintain the spiral of violence and pollution that is now entering a critical phase.

The generalized crisis of communication can be viewed in two inter-related ways. Contrary to the idea that the Anthropocene is 'unthinkable' (Lederer \& Kreuter, 2018) or that it defeats organizational rationalities (Campbell, McHugh \& Ennis, 2019), or even that it blurs boundaries between actors (Reichel \& Perey, 2018), we have argued that our ways of reasoning no longer connect with one another because we talk as though the space through which our messages pass is under our control. We fail to see that those messages become deferred, distorted and transformed between speakers and practice. In a sense, we live amidst an excess of reasoning, but since it depends on the exclusion of the middle space, we lack the ability to weave together its various forms. No amount of fact-checking or correct messaging will bring humanity together to face up to the Anthropocene without recognising the role of the middle space in grounding and disrupting communication. As Latour (2018: 25) declaims "it is not a matter of learning how to repair cognitive deficiencies, but rather of how to live in the same world".

The second aspect is the loss of communicative bonds to the Earth itself. Serres points to the ways in which ancient human societies personalized natural events - "beneath rumbling Etna's chimneys, our Ancients believes that Vulcan, a blacksmith, was striking the anvil with a sledgehammer; that Jupiter, from Mt. Olympus, was hurling thunder and lightning, bursting in the ears" (Serres, 2012: 34). Rather than treat this as an example of a pre-rational, misguided spiritualism, Serres argues that the ability to see that these events were connected to a force which was entirely outside of human causal action and control served to link communities to the Earth System. Do not many of our current problems around climate change stem from a contrary inability to see orange skies, declining bird song and unexpected flooding as utterances within a kind of conversation we are having with the Earth 
System? Unlike our Neolithic ancestors, who dwelled amongst the creatures they parasitized in such a way that they were acculturated into an ongoing communicative exchange, we now live as though we were mutely 'on' the Earth System rather 'within' it.

What we have proposed as a means for Business and Management Schools to face up to the Anthropocene is a general programme of 'slowing down'. This phrase has very specific meanings for us. We are not suggesting that the pace of activity within business and management schools should be slowed (although this might in itself be welcomed by many academics). Nor are we suggesting that, at a broader level, social, economic, scientific or technological organizing should be deliberately slackened. The window for implementing measures to address climate change is incredibly small and there are a great many things that need to happen very quickly. Rather, what we principally mean is a slowing down in the ways that we formulate problems and construct models, accompanied by an adjusting of human and organizational temporalities to that of other actors within the Earth System. As Isabelle Stengers (2017) argues in her 'manifesto for slow science', the race for 'solutions' has created a competitive and crowded space of ideas which neglects to build the necessary consensus within both human publics and with the non-human actors who will also need to be part of any implementation. Moreover, it becomes impossible to either anticipate or report 'failure'. As pataphysics makes clear, failure is an integral part of human experience. The drive to be supposedly 'useful' or to 'succeed' destroys imagination and binds us ever more tightly to our partial 'anthropomorphic perceptions' (Launoir, 2005).

The most obvious way in which 'slowing down' needs to be embedded within business and management education is in the general injunction to decelerate the parasitic activities of modern globalized economies. The lessons of parasite logic are very clear. Life itself is parasitic, in the sense that order is 'borrowed from somewhere else' (Serres, 1982a). But organisms which operate in an entirely parasitic mode tend to have a relatively short life 
span, and none has ever achieved the level of global dominance of contemporary human civilization. Parasitism, for Serres, is a play of substitutions, where actors shift between the roles of parasite and parasitized (e.g. host). The most important point of instruction here is that social and economic organizing needs to be able to alternate between these positions. This involves something more than simply adding in measures to 'offset' the effects of parasitic activities (Cable et al., 2017). It requires sustained reflection on the ways that organizations can give themselves over graciously and willingly to serve as hosts.

Contra to Berg \& Seeber's (2016) description of the teachings of a 'slow professor', it is unlikely that this injunction against the 'great acceleration' of modern business will be sufficient by itself. This is where we see a pivotal role for the kinds of techniques and intellectual strategies developed within pataphysics. For example, converting problemsolving tasks from an either/or to a both/and format, thereby emphasising the plus-minus or antimony, creates a situation where not only is there no 'right' or 'wrong' answer, but there is also no obvious criterion for success. Everything is failure, and as a pataphysical consequence, everything is equally interesting and worthy of debate. Izak (2015) suggests that business and management rationality should not be approached in a functionalist manner, but we would argue that what is needed is to shift even further away from a fixation on solutions and success towards a 'dis-functional' approach where objects and organisms are liberated from instrumentality, and use more a divergent reasoning. Pataphysics subjects dominant modes of rationality to a divergent thinking of the absurd and proposes playful forms of reasoning, which allows a different approach to learning. As Jarry (1965b) noted, a functional description is only ever a partial, perspectival account that fails to grasp things in their pataphysical dimension - i.e. all of the possible states and relations that they might enter into. Newark (2017) identifies the 'logic of absurdity' as a potential option for leaders which may create anomalous and outstanding decisions. Following the pataphysical notion that 
everything is an anomaly, we recommend a rigorous absurdity as the default mode of reasoning. Absurdity is a powerful tool for relentlessly pursuing a series of propositions at escalating levels of implausibility. But it is also a device for demonstrating how the scaling up of apparently rational solutions can lead in to the utterly irrational. For example, industrial farmed or 'broiler' chickens are the world's most numerous birds with a standing population of 22.7 billion (Bennett et al., 2018). Since the mid-20th century, broiler growth rates have soared, and the chickens have up to a fivefold increase in individual biomass and are incapable of surviving on their own. These birds have been modified by humans to have more meat on them to the point that they need to be killed young (they have maximum sevenweek span); beyond this the modern broiler would grow with a wide body shape, a low centre of gravity and multiple osteo-pathologies, reduced pelvic muscles, decreased size of lungs and heart. It would not survive to maturity. We need to teach business and management students, through a playful learning, that every idea needs to be subjected to a rigorous conceptual absurdity before it becomes an empirical manifestation of human disgust and anthropocenic tragedy.

The broiler chicken example vividly demonstrates the relationship between parasitism and 'living together' or symbiosis. When parasite and host live together within the same immediate environment, a circulation between positions is more likely. The uninvited guest, for instance, cannot always take without giving because they risk expulsion. They must find ways to take on the position of host, even if momentarily. But when humans no longer live together with the organisms they parasitize, the necessity of exchanging positions becomes ignored, with devasting consequences. In the case of broiler chickens and other industrially farmed animals, anomalous maturation conditions require the use of antibiotics to guard against infections. These then enter into the food chain, creating higher trace levels of 
antibiotic drugs amongst human populations, resulting in turn in increased antimicrobial resistance. In this way, the parasites become parasitized in turn by other parasites.

The alternative is to work towards the kind of mutualistic relationships that define slow design-driven organizations. Here there is typically a proximity between organizations and their supply chains that enables operative communicative relations, and, as a consequence, a circulation of positions between host and parasite. For example, recycling might be seen as a problem that does not immediately concern producers beyond ensuring the sustainable nature of the resources they use. But products such as biodegradable garments close the loop by creating a relationship between outputs and inputs to the production process. Slow-design driven organizations then become entangled in multiple spatial and temporal relationships (e.g. closeness to supply chains; anticipating the time of biodegradation). Mutualism is the fundamental basis on which we may begin to find ways to 'master' our own 'mastery'. We suggest that businesses need to recognize relationships of mutual dependency with the Earth System, rather than treating 'natural resources' as 'externalities' needs to be made central to how we develop economic and business models.

Serres (1995a) argues that recognition in itself will not be sufficient - we need to accord a formal status as speaking subjects to the myriad actors of the Earth System. This goes beyond Heikkurinen et al.'s (2019) call to accord a form of agency to non-human actors (for an early critique of this proposition in relation to Actor-Network Theory see Lee \& Brown, 1994). Whilst it might seem wildly implausible that non-humans could hold the kinds of legal and speaking rights usually reserved for humans, the structure and organization of the Collège de 'Pataphysique demonstrates otherwise. This is an eight-decade old organization that has been led by a crocodile, that includes persons legally registered as deceased as active participant members, and which treats humans, non-humans and imaginary beings as having equal status as members. Pataphysics provides empirical proof of concept that it is possible to 
organize with a definition of humanity and rights that departs from normative conceptions, and which paves the way for how we may be forced to think about the nature of 'humanity' in order to confront the Anthropocene (Raffnsøe, 2016). We suggest including pataphysics as a methodology to support management learning in the Anthropocene, since pataphysics can support reasoning with the included and the excluded, with actors that are present in the Anthropocene but not yet not visible in organizations. O’Doherty (2007, pg. 857) suggests that pataphysics

"Long resigned to the impossibility of representation that avoids the entanglement and active participation of the subject in the construction of its 'object' it seems that we can only know or understand 'reality' through participation (which is inevitable). However minor or insignificant it might seem, this entangled form of representation and storytelling always-already enacts change. By deflecting the mundane order with their apostrophes and interruptions that make us look twice, 'pataphysicians help us see the boundaries and limitations of what we routinely accept as organizational reality". Crucial to learning in the Anthropocene will be the development of 'imaginary solutions' grounded within data and approaches that depart significantly from underpinning 'business as usual' models. We call for rigorously structured absurdity, rather than pure irrationality, as a strategy to face up to and seek to overcome the horror of unrestrained hominescence. Introducing and integrating geological principles in the Business Schools, through a mode that is simultaneously serious and non-serious, would allow exploration and better learning of the materiality of things, of how each entity makes an impact on the Earth System, slowing down the reasoning, and lead to different learning-by-doing in decision-making through divergent thinking. Management learning education has previously addressed divergent forms of reasoning, such as employing emancipatory modes of sensemaking in foolishness (March, 2006) or absurdity (Nerwak, 2018). Foolishness can facilitate learning in an 
unmanaged organizational space, since it is a blame-free approach encouraging risk taking, promoting openness towards original ideas, and enhancing an organization's propensity to challenge its own assumptions (Izak, 2015). Similarly, the logic of absurdity rejects the functionalistic view. An absurd rationality depicts decision making in which irrationality is recognized, action alternatives are identified and assessed according to their expected consequences and desirability, and yet a rationally unjustifiable course of action is still chosen (Nerwak, 2018). Our paper adds to this literature by suggesting that the playful forms of reasoning and learning in pataphysics are absurd, in such a way that absurdity depicts irony and symbolic truths, devoid of purpose, metaphysical uselessness and senselessness (Grossman,1967), and helps challenging the dominant approach.

Mutualism may also serve as the basis for how problems are framed within business and management education and learning. It is well established that our curriculums need to be reworked to include cross-cultural dimensions, to be sensitive to historical changes, and to rise to the challenge of decolonialization. We would argue that facing up to the Anthropocene requires that this work needs to move to further stage of dehominization. Much of what we teach in Business and Management schools is framed using forms of reason that are entirely anthropocentric - that is, in terms of human desires, needs, intentions etc. But this framing of problems is being systematically undermined from two different direction. If Haff (2014) is correct in his assertion that the technosphere has a kind of aggregate autonomy that eludes human mastery, then we must enquire as to what 'it' wants, where it is going. Equally, we need to know how other organisms in the Earth System are responding to climate change, and the directions of travel that they are moving towards. Our limited human-centric conceptions of agency are a real obstacle here. We need to know what strategic marketing is for a machine-learning bot, we must learn what competitive advantage looks like for a tadpole. We need to speak to the Earth about its preferred leadership style as we meet the headroom for 
human survival. We "have all things in hand but we do not control our actions" (Serres \& Latour, 1995: 70). We need to help our students to find ways to speak and listen to the actual manager.

Writing this paper together has been an experiment in interdisciplinarity. The idea that there is a kind of 'plug in and play' relationship between different disciplines seems to still dominate how funding bodies and supranational organizations think about collaborative work. It has not been like that for us. It resembles instead the kind of 'adventure' that Serres describes, or the type of surprise Jarry talks about in looking at an object that embodies, within itself, multiple perspectives. Talking across disciplines leads into a journey through points unknown and unexpected. This is not easy. It requires continuous negotiation about propositions, about what is and is not sayable, about the evidence which can be mobilized, and, critically, the forms of reasoning which can make sense of it all. We see this piece, for all its flaws, as an example of how we need to collaboratively trust one another to let go of the established lineaments of our thinking and enter into imaginative, perhaps even absurd solutions to our collective Anthropocenic futures.

\section{REFERENCES}

Akrivou, K. \& Bradbury-Huang, H. 2015. Educating integrated catalysts: Transforming business schools toward ethics and sustainability. Academy of Management Learning \& Education, 14(2): 222-240. https://doi.org/10.5465/amle.2012.0343.

Beacham, J. 2018. Organising food differently: Towards a more-than-human ethics of care for the Anthropocene. Organization, 25(4): 533-549. https://doi.org/10.1177/13505 08418777893.

Bennett, C. E., Thomas, R., Williams, M., Zalasiewicz, J., Edgeworth, M., Miller, H., ... Marume, U. 2018. The broiler chicken as a signal of a human reconfigured biosphere. 
Royal Society Open Science, 5(12). https://doi.org/10.1098/rsos.180325.

Berg, M., \& Seeber, B. 2016. Slow Professor: Challenging the Culture of Speed in the Academy. Toronto: University of Toronto Press.

Bök, C. 2002. Pataphysics: The poetics of an imaginary science. Evanston, IL: NorthWestern University Press.

Brown, S. D. 2002. Michel Serres. Theory, Culture \& Society, 19(3): 1-27. https://doi.org/10.1177/0263276402019003001.

Brown, S. D. 2005. The theatre of measurement: Michel Serres. Sociological Review, 53(Suppl. 1): 215-227. https://doi.org/10.1111/j.1467-954X.2005.00551.x.

Brown, S. D. 2016. They have escaped the weight of darkness: The problem space of Michel Serres. In C. Steyaert, T. Beyes, \& M. Parker (Eds.), The Routledge Companion to Reinventing Management Education: 144-160. London: Routledge.

Brown, S. D., \& Reavey, P. 2017. Dark organizational theory. Journal of Cultural Economy, 10(3): 1-16. https://doi.org/10.1080/17530350.2017.1298533.

Brueckner, M., Spencer, R., \& Paull, M. (Eds.). 2018. Disciplining the undisciplined? Perspectives from business, society and corporate social responsibility and sustainability. Cham, Switzerland: Springer International Publishing. https://doi.org/10.1007/978-3-319-71449-3.

Cable, J., Barber, I., Boag, B., Ellison, A. R., Morgan, E. I., Murray, K., Pascoe, E. I, Sait, S. I, Wilson, A. J., \& Booth, M. 2017. Global change, parasite transmission and disease control: Lessons from ecology. Philosophical Transactions of the Royal Society B: Biological Sciences 372 (1719). https://doi.org/10.1098/rstb.2016.0088.

Callon, M. 1980. The social process of scientific investigation. In K. Korr, R. Krohn, \& R. Whitley (Eds.), Struggles and negotiations to define what is problematic and what is not: 197-219. Dordrecht, Netherlands: Springer. https://doi.org/10.1007/978-94-009- 
9109-5_8.

Callon, M. 1998. The laws of the markets (Vol. 6). Oxford, UK: Blackwell.

Campbell, N., McHugh, G., \& Ennis, P. J. 2019. Climate change is not a problem:

Speculative realism at the end of organization. Organization Studies, 40(5): 725-744. https://doi.org/10.1177/0170840618765553.

Choquet, P. L. 2019. Piercing the corporate veil: Towards a better assessment of the position of transnational oil and gas companies in the global carbon budget. Anthropocene Review, 6(3): 243-262. https://doi.org/10.1177/2053019619 $\underline{865925}$.

Cooper, R. 1986. Organization/disorganization. Social Science Information, 25(2): 299-335.

Cooper, R. 1991. Formal organization as representation: Remote control, displacement and abbreviation. In M. Reed and M. Hughes (Eds.), Rethinking organization: 254-272. London: Sage.

Cutcher, L. 2014. Bringing back the bank: Local renewal and agency through community banking. Organization Studies, 35(1): 103-19. https://doi.org/10.1177/01708406 13495337.

Dalby, S. 2015. Anthropocene formations: Environmental security, geopolitics and disaster. Theory, Culture \& Society, 34(2-3): 233-252.

Dalby, S. 2016. Framing the Anthropocene: The good, the bad and the ugly. Anthropocene Review, 3(1): 33-51. https://doi.org/10.1177/2053019615618681.

Dalby, S. 2018. Firepower: Geopolitical cultures in the Anthropocene. Geopolitics, 23(3): 718-742. https://doi.org/10.1080/14650045.2017.1344835.

Debs, P. 2013. Alma Mater Studiorum - Università Di Bologna Dottorato Di Ricerca. In Economia E Politica Agraria Ed Alimentare Ciclo XXV. Analysis of the slow food movement impact on the farmers and rural areas. Sustainable Development Presentation. PhD Alma Mater Studiorum: Università di Bologna. 
https://core.ac.uk/download/pdf/17332798.pdf.

De Duve, T. 1987. The definitively unfinished Marcel Duchamp. Cambridge, MA: MIT Press.

De Duve, T. 1989. Résonances du ready-made: Duchamp entre avant-garde et tradition. Nîmes: Jacqueline Chambon.

De Duve, T. 1998. Kant after Duchamp. Cambridge, MA: The MIT Press.

De Duve, T. 2005. Pictorial nominalism: On Marcel Duchamp's passage from painting to the readymade. Minneapolis: University of Minnesota Press.

Desjeux, I. 2010. The parasitic cycle of reliquum. Reliquum: A Field Survey. Ideas as parasites: Failomics.

Edwards, P. N. 2017. Knowledge infrastructures for the Anthropocene. Anthropocene Review, 4(1): 34-43. https://doi.org/10.1177/2053019616679854.

Evergreen Review. 1960. What is 'Pataphysics? Evergreen Review, 4(13).

Foulc, T. 2007. Approche spatio-temporelle de sa magnificence lutembi. Carnets Trimestriels Du Collège de 'Pataphysique, 28: 45-61.

Frattini, F., Dell'Era, C., \& Rangone, A. 2013. Launch decisions and the early market survival of innovations: An empirical analysis of the Italian mobile value-added services (VAS) industry. Journal of Product Innovation Management, 30(S1): 174187. https://doi.org/10.1111/jpim.12070.

Gasparin, M., Green, W., \& Schinckus, C. forthcoming. Slow design-driven innovation: A response to our future in the Anthropocene epoch. Creativity and Innovation Management.

Gasparin, M., Schinckus, C., \& Green, W. 2019. Thinking outside the box to get inside the black box: Alternative epistemology for dealing with financial innovation. Social Epistemology, 33(3): 218-233. https://doi.org/10.1080/02691728.2019.1601290. 
Ghosh, A. 2016. The great derangement: Climate change and the unthinkable. Chicago: University of Chicago Press.

Görg, C., Plank, C., Wiedenhofer, D., Mayer, A., Pichler, M., Schaffartzik, A., \& Krausmann, F. 2019. Scrutinizing the great acceleration: The Anthropocene and its analytic challenges for social-ecological transformations. Anthropocene Review, 1-20. https://doi.org/10.1177/2053019619895034.

Griffiths, A. J., Giannantonio, C. M., Hurley-Hanson, A. E., \& Cardinal, D. 2016. Autism in the workplace: Assessing the transition needs of young adults with Autism Spectrum Disorder. Journal of Business and Management, 22(1), 5-22.

Grossman, M. L . 1967. Alfred Jarry and the Theatre of the Absurd. Educational Theatre Journal 19 (4): 473-77.

Haff, P. 2014. Humans and technology in the Anthropocene: Six rules. Anthropocene Review, 1(2): 126-136. https://doi.org/10.1177/2053019614530575.

Haff, P. 2019. The technosphere and its physical stratigraphic record. In J. Zalasiewicz, C. N. Waters, M. Williams, \& C. P. Summerhayes (Eds.), The Anthropocene as a geological time unit: A guide to the scientific evidence and current debate: 137-155. Cambridge, UK: Cambridge University Press. https://doi.org/10.1017/9781108621359.004.

Helgason, T., Daniell, T. J., Husband, R., \& Mycorrhizal, H. 1998. Ploughing up the woodwide web? Nature, 394(July): 431.

Hodgson, D., \& Briand, L. 2013. Controlling the uncontrollable: Agile teams and illusions of autonomy in creative work. Work, Employment \& Society, 27(2): 308-325. https://doi.org/10.1177/0950017012460315.

Holt, R. 2018. Judgement and strategy. Oxford: Oxford University Press. https://doi.org/10.1093/oso/9780199671458.001.0001.

Holt, R., \& Johnsen, R. 2019. Time and organization studies. Organization Studies, 40(10): 
1557-1572. https://doi.org/10.1177/0170840619844292.

Hugill, A. 2012. 'Pataphysics: A useless guide. Cambridge, MA: MIT Press.

Izak, M. 2015. Learning from a fool: Searching for the 'unmanaged' context for radical learning. Management Learning, 46(1): 87-104. https://doi.org/10.1177/1350507613 486426.

Jarry, A. 1965a. Exploits and opinions of Doctor Faustroll, pataphysician: A scientific novel, trans. Simon Watson Taylor. London: Grove Press.

Jarry, A. 1965b. Selected works of Alfred Jarry. (R. Shattuck \& S. Watson, Eds.). London: Methuen.

Klein, N. 2015. This changes everything: Capitalism vs. the climate. Simon and Schuster.

Knauss, J., Lill, G., \& Maxwell, A. 1998. Recounting the history of the Albatross Award. EOS: Transactions American Geophysical Union, 79(3): 31-35. https://doi.org/10.1029/98EO00022.

Kohn, E. 2013. How forests think toward an anthropology beyond the human. Oakland, CA: University of California Press.

Latour, B. 1987. Science in action: How to follow scientists and engineers through society. Cambridge, MA: Harvard University Press.

Latour, B. 1992. Where are the missing masses? The sociology of a few mundane artifacts. In W. Bijker and J. Law (Eds.), Shaping technology/building society: Studies in sociotechnical change. Cambridge MA: MIT Press.

Latour, B. 1994. On technical mediation: Philosophy, sociology, genealogy. Common Knowledge, Fall V3(2): 29-64.

Latour, B. 2004. Politics of nature: How to bring the sciences into democracy. Cambridge, MA: Harvard University Press.

Latour, B. 2017. Facing Gaia: Eight lectures on the new climatic regime. Cambridge, UK; 
Medford, MA: Polity Press.

Latour, B. 2018. Down to earth: Politics in the new climatic regime. Cambridge, UK; Medford, MA: Polity Press.

Launoir, R. 2005. Clefs pour la 'Pataphysique. Paris: L'Hexaèdre.

Lederer, M., \& Kreuter, J. 2018. Organising the unthinkable in times of crises: Will climate engineering become the weapon of last resort in the Anthropocene? Organization, 25 (4): 472-90. https://doi.org/10.1177/1350508418759186.

Lee, N., \& Brown, S. 1994. Otherness and the actor network. American Behavioral Scientist, 37(6): 772-790.

Li, C. Z., Crépin, A. S., \& Folke, C. 2018. The economics of resilience. International Review of Environmental and Resource Economics, 11(4), pp.309-353.

Linstead, S., Maréchal, G., \& Griffin, R. W. 2014. Theorizing and researching the dark side of organization. Organization Studies, 35(2): 165-188. https://doi.org/10.1177/01708 40613515402.

Manzini, E. 2014. Making things happen: Social innovation and design. Design Issues, 30(1): 57-66. https://doi.org/10.1162/DESI.

March, J. 2003, Rationality, foolishness, and adaptive intelligence. Strategic Management Journal, 27: 201-214. https://doi.org/10.1002/smj.515

Mitchell, A. S., Lemon, M, \& Lambrechts. W. (2020). Learning from the Anthropocene: Adaptive Epistemology and Complexity in Strategic Managerial Thinking. Sustainability 12 (11): 4427. https://doi.org/10.3390/su12114427.

Mychajliw, A. M., Kemp, M. E., \& Hadly, E. A. 2015. Using the Anthropocene as a teaching, communication and community engagement opportunity. Anthropocene Review, 2(3): 267-278. https://doi.org/10.1177/2053019615601444.

Netherlands Academy of 'Pataphysics, The, (NAP). 1972. Woudagemaal, the largest steam 
pumping engine in the world. De Nederlandse Academie voor 'Patafysica. http://www.batafysica.nl.

Nyberg, D., Spicer, A., \& Wright, C. 2013. Incorporating citizens: Corporate political engagement with climate change in Australia. Organization, 20(3): 433-453. https://doi.org/10.1177/1350508413478585.

Nyberg, D \& Wright, C. 2020. Climate-Proofing Management Research. Academy of Management Perspectives, March. https://doi.org/10.5465/amp.2018.0183.

O'Doherty, Damian. 2007. The Question of Theoretical Excess: Folly and Fall in Theorizing Organization. Organization 16 (6): 837-67.

Perec, G. 1968. Pataphysics. Paris: Collège de 'Pataphysique.

Perec, G. 1969. La Disparition. Trans. A Void. Paris: Editions Gallimard; London: Penguin. Povinelli, E. A. 2016. Geontologies: A requiem to late liberalism. Durham, NC: Duke University Press.

Raffnsøe, S. 2016. Philosophy of the Anthropocene: The human turn. London: Palgrave Macmillan. https://doi.org/10.1057/9781137526700.

Reichel, A., \& Perey, R. 2018. Moving beyond growth in the Anthropocene. Anthropocene Review, 5(3): 242-249. https://doi.org/10.1177/2053019618799104.

Roux-Rosier, A., Azambuja, R., \& Islam, G. 2018. Alternative visions: Permaculture as imaginaries of the Anthropocene. Organization, 25(4): 550-572. https://doi.org/10.1177/1350508418778647.

Serres, M. 1982a. The parasite. Minneapolis, MN: Upress.

Serres, M. 1982b. Hermes: Literature, science, philosophy. Baltimore, MD: John Hopkins.

Serres, M. 1989. Detachment. Athens: Ohio University Press.

Serres, M. 1995a. The natural contract. Ann Arbor: University of Michigan Press.

Serres, M. 1995b. Angels: A modern myth. Paris: Flammation. 
Serres, M. 2011. Malfeasance: Appropriation through pollution? Stanford, CA: Stanford University Press.

Serres, M. 2012. Biogea. Minneapolis, MN: Univocal Publishing.

Serres, M. 2015. Rome: The first book of foundation. London: Bloomsbury.

Serres, M. 2018. The incandescent. London: Bloomsbury.

Serres, M. 2019. Hominescence. New York, NY: Bloomsbury Academic Publishing.

Serres, M., \& Latour, B. 1995. Conversations on science, culture, and time. Ann Arbor, MI: University of Michigan Press. https://doi.org/10.3998/mpub.97336.

Steffen, W., Crutzen P. J., \& McNeill, J. 2007. The Anthropocene: Are humans now overwhelming the great forces of nature. AMBIO: A Journal of the Human Environment, 36(8): 614-621.

Steffen, W., Grinevald, J., Crutzen, P., \& McNeill, J. 2011a. The Anthropocene: Conceptual and historical perspectives. Philosophical Transactions of the Royal Society A: Mathematical, Physical and Engineering Sciences, 369(1938): 842-867. https://doi.org/10.1098/rsta.2010.0327.

Steffen, W., Persson, Å., Deutsch, L., Zalasiewicz, J., Williams, M., Richardson, K., ... Svedin, U. 2011b. The Anthropocene: From global change to planetary stewardship. Ambio, 40(7): 739-761. https://doi.org/10.1007/s13280-011-0185-x.

Steffen, W., Rockström, J., Richardson, K., Lenton, T. M., Folke, C., Liverman, D., ... Schellnhuber, H. J. 2018. Trajectories of the Earth System in the Anthropocene. Proceedings of the National Academy of Sciences, 115(33): 8252-8259. https://doi.org/10.1073/pnas.1810141115.

Steffen, W. 2019. The Anthropocene: Where on earth are we going? The Ecological Citizen, 2(2): 129-130.

Stengers, I. 2017. Another science is possible: A manifesto for slow science. Cambridge: 
Polity Press.

Strauss, C. F., \& Fuad-Luke, A. 2008. The slow design principles A new interrogative and reflexive tool for design research and practice. Changing The Change: Design Visions, Proposals and Tools, 1-14. www.slowlab.net.

Tsing, A.L. 2016. The mushroom at the end of the world: On the possibility of life in capitalist ruins. Princeton, NJ: Princeton University Press.

Vince, R. 2019. Institutional illogics: The unconscious and institutional analysis.

Organization Studies, 40(7): 953-973. https://doi.org/10.1177/0170840618765866.

Waters, C. N., Zalasiewicz, J., Summerhayes, C., Barnosky, A. D., Poirier, C., Gałuszka, A., ... Wolfe, A. P. 2016. The Anthropocene is functionally and stratigraphically distinct from the Holocene. Science, 351(6269). https://doi.org/10.1126/science.aad2622.

Whitehead, A. N. 1920/2004. Theories of the bifurcation of nature. In The Concept of Nature, 26-48. Cambridge, UK: Cambridge University Press.

Williams, M., Zalasiewicz, J., Aldridge, D., Waters, C., Bault, V., Head, M., \& Barnosky, A. 2019. The biostratigraphic signal of the neobiota. In J. Zalasiewicz, C. N. Waters, M. Williams, \& C. Summerhayes (Eds.), The Anthropocene as a geological time unit: 119-127. Cambridge, UK: Cambridge University Press. https://doi.org/10.1017/978110 8621359.

Williams, M., Zalasiewicz, J., Haff, P. K., Schwägerl, C., Barnosky, A. D., \& Ellis, E. C. 2015. The Anthropocene biosphere. Anthropocene Review, 2(3): 196-219. https://doi.org/10.1177/2053019615591020.

Wohlleben, P. 2017. The hidden life of trees: What they feel, how they communicate:

Discoveries from a secret world. London: William Collins.

Wright, C., Nyberg, D., Rickards, L., \& Freund, J. 2018. Organizing in the Anthropocene. Organization, 25(4): 455-471. https://doi.org/10.1177/1350508418779649. 
Yusoff, K. 2018. Politics of the Anthropocene: Formation of the commons as a geologic process. Antipode, 50(1): 255-276. https://doi.org/10.1111/anti.12334.

Zalasiewicz, J. Williams, M., Waters, C. N, Barnosky, A., \& Haff, P. 2014. The technofossil record of humans. Anthropocene Review, 1(1): 34-43. https://doi.org/10.1177/20530 19613514953.

Zalasiewicz, J., Waters, C. N., Williams, M., Barnosky, A. D., Cearreta, A., Crutzen, P., ... Oreskes, N. 2015. When did the Anthropocene begin? A mid-twentieth century boundary level is stratigraphically optimal. Quaternary International, 383: 196-203. https://doi.org/10.1016/j.quaint.2014.11.045.

Zalasiewicz, J., Waters, C., Summerhayes, C., \& Williams, M. 2018. The Anthropocene. Geology Today, 34(5): 177-181. https://doi.org/10.1111/gto.12244.

Zalasiewicz, J., Waters, C., Williams, M., \& Summerhayes, C. 2019. The Anthropocene as a geological time unit: A guide to the scientific evidence and current debate. Cambridge, UK: Cambridge University Press. https://doi.org/10.1017/9781108621359. Zalasiewicz, J., Williams, M., Waters, C. N., Barnosky, A. D., Palmesino, J., Rönnskog, A. S., ... Wolfe, A. P. 2017. Scale and diversity of the physical technosphere: A geological perspective. Anthropocene Review, 4(1): 9-22. https://doi.org/10.1177/ 2053019616677743. 